\title{
Growth characteristics of noiler chickens as determined by nonlinear algorithms
}

Adamu, J., Shuaibu, A. Y. and Raji, A. O.

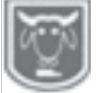

Department of Animal Science, University of Maiduguri,

Maiduguri, Borno State.

Abstract

*Corresponding author: Jummaiyalma1@gmail.com

The assessment of growth characteristics of noilers chickens as determined by non-linear algorithms will provide the best mathematical function in the growth of male and female noilers chickens. This study sought to determine the adequacy of two mathematical functions for modeling growth characteristics of male and female Noiler ${ }^{\circledR}$ chickens. Body weights and morphometric traits of 200 Noiler chickens were measured bimonthly for 20 weeks and the data obtained fitted to the Gompertz and Logistic growth models using the nonlinear regression. The results showed significant $(P<0.05)$ difference between males and females only at 16, 18 and 20 weeks of age, with values of $2316.2 \mathrm{vs} 2121.9 \mathrm{~g}, 2624.3 \mathrm{vs} 2378.1 \mathrm{~g}$, and 3002.7 vs 2718.7g, respectively. There were no discernable differences between males and females for most body measurements except body length which was longer in the latter than former from 14 weeks of age. The asymptomatic weight (A) of the models revealed that Gompertz model had higher values for both male and female Noilers than the Logistic for body weight and all morphometric traits. The reverse was observed with the scale parameter $(B)$ and relative growth rate $(C)$ for all traits. The coefficient of determination $\left(R^{2}\right)$ values for both models (male and female) were generally high $(>80 \%)$ indicating a good fit for the data. The other goodness of fit criteria; Akaike Information Criterion (AIC) and standard deviation (SD) were lower for the Gompertz compared to Logistic for both male and female. Thus, the study revealed that the Gompertz was the better model for explaining the growth patterns of both male and female Noiler chickens.

Keywords: Models, noiler, body weight, Morphometric traits

\section{Caractéristiques de croissance des poulets noilers déterminés par des algorithmes non linéaires}

\section{Résumé}

$\overline{\text { L'évaluation des caractéristiques de croissance des poulets de Noilers tels que déterminées }}$ par des algorithmes non linéaires fournira la meilleure fonction mathématique de la croissance des poulets de Noilers masculins et féminins. Cette étude a cherché à déterminer l'adéquation de deux fonctions mathématiques pour la modélisation des caractéristiques de croissance des poulets mâles et femelles Noiler. Les poids corporels et les traits morphométriques de 200 poulets nilaques ont été mesurés bimenshly pendant 20 semaines et les données obtenues dans les modèles de Gompertz et croissance logistiques utilisant la régression non linéaire. Les résultats ont montré une différence significative $(p<0,05)$ entre les mâles et les femmes seulement à 16, 18 et 20 semaines, avec des valeurs de 2316,2 vs $2121,9 \mathrm{~g}, 2624.3$ contre $2378,1 \mathrm{~g}$ et $3002,7 \mathrm{vs} 2718.7 \mathrm{~g}$, respectivement. Il n'y avait pas de différences discernables entre les hommes et les femmes pour la plupart des mesures du corps, à l'exception de la longueur du corps, ce qui était plus long que l'ancien de 14 semaines. Le poids asymptomatique (A) des modèles a révélé que le modèle de Gompertz avait des valeurs plus élevées pour les noilers mâles et femelles que la logistique pour le poids corporel et tous les traits morphométriques. L'inverse a été observé avec le paramètre d'échelle (B) et le taux de croissance relative (C) pour tous les traits. Le coefficient de valeurs 
de détermination $\left(R^{2}\right)$ pour les deux modèles (hommes et femmes) était généralement élevé $>$ $80 \%$ ) indiquant un bon ajustement pour les données. L'autre bonté des critères d'ajustement; Le critère d'information Akaike (CIA) et l'écart type (ET) étaient plus bas pour le Gompertz par rapport à la logistique pour les hommes et les femmes. Ainsi, l'étude a révélé que le Gompertz était le meilleur modèle d'explication des schémas de croissance des poulets mâles et femelles Noilers.

Mots-clés: Modèles, noiler, poids corporel, sexe, morphométrique, traits

\section{Introduction}

Poultry production is one of the best means for production of high biological value animal protein in terms of eggs and meat (Yakubu et al., 2007). The poultry sector contributes about $25 \%$ of the agricultural domestic products of the Nigerian economy (FAO, 2010). Nigeria presently produces above $550,000 \mathrm{mt}$ of poultry meat per annum and 770,000 $\mathrm{mt}$ of eggs (FAO, 2010). Poultry meat and eggs account for about $30 \%$ of total livestock output in Nigeria, of which eggs account for over 80 percent (Fayeye et al., 2005). Ogundipe and Sanni (2002) reported that poultry production plays an important role in contributing to income as well as nutritional status of the country. Mathematical functions called growth models (each with a non-linear structure and sigmoid shape) have been used to explain the growth patterns of poultry species (Narine et al., 2017). The main advantage of nonlinear models is parsimony, interpretability and prediction (Bates and Watts, 2007). Growth curve parameters are highly heritable and have been widely exploited in poultry selection studies (Maginon-Grasteav, 2001). Studies had been carried out for the prediction of future growth at any age in poultry (Raji et al., 2014). Feeding regimens can be determined using mathematical model in addition to the nutritional requirements at various growth stages (Selvaggi et al., 2015). The Noiler is a dual purpose breed of chicken developed by Amo farm Sieberer Hatchery Limited for small holders to address the challenges of food insecurity and financial dependency among rural populace especially women. It has been emphasized that the introduction of tropically adapted genotypes with high performance is beneficial to the resource poor poultry farmers (Yakubu and Ari, 2018). Knowledge of growth of Noiler birds is important to evaluate their development at all ages. Thus, the objective of this study was to determine the effect of sex on body weight and morphometric traits as well as the appropriate model for describing growth of Noiler chickens.

\section{Materials and methods \\ Experimental animal and management}

A total of 200 day old Noiler chicks were obtained from a reputable hatchery. The birds were brooded for three weeks on wood shavings using coal pots to supply heat, after which they were placed under deep litter management system for 140 days (20 weeks). All the birds were tagged individually for proper identification. They were fed with a commercial chick mash (1-8 weeks) containing $3000 \mathrm{kcal} / \mathrm{kg}$ of energy and $20 \%$ Crude protein (CP) and grower mash $(8-20$ weeks $)$ containing $2650 \mathrm{Kcal} / \mathrm{kg}$ of energy and $16 \%$ crude protein $(\mathrm{CP})$. Clean water and feed were given ad libitum and routine vaccination and other management practices were strictly adhered to.

\section{Data collection and models}

The body weight and morphometric traits were measured for each bird once every two weeks for the duration of the experiment thus:

Body weight: This was taken using a weighing balance calibrated in grams $(\mathrm{g})$. 
Body Length: This was measured as distance between the base of the neck to the tail end.

Shank Length: This was measured as the length of the tarso-metatarsus from the hock joint.

Thigh length: This was measured as distance between the hock joints and pelvic joints.

Wing length: This was measured from the tip of the right wing to the tip of the left wing.

Chest girth: This was measured as the circumference of the breast around the deepest region of the breast.

All the data collected were fitted into the following growth models

1. Logistic model's: the following equation describes the Logistics (Roberison,1923) growth model $\mathrm{Wt}=\mathrm{Wa} /[1+\exp -\mathrm{K}(\mathrm{t}-\mathrm{Ti})]$ where:

$\mathrm{Wt}=$ the body weight at time $\mathrm{t}$, $\mathrm{Wa}=$ asymptptic body weight, $\mathrm{K}=$ the exponential growth rate, and Ti the age at the inflection point.

2. Gompertz-Laird model: the laird form of the Gompertz equation (Laird et al.,1965) was fitted to the data. The following equation describes the Gompertz-Laird growth curve;

$\mathrm{Wt}=\mathrm{Wo}_{\text {exp }}\left[(\mathrm{L} / \mathrm{K})\left(1-_{\exp } \mathrm{Kt}\right)\right]$

Where:

$\mathrm{Wt}=$ weight of bird at time $\mathrm{t}$,

Wo = initial body (hatch) weight,

$\mathrm{K}=$ rate of exponential decay of the initial specific growth rate,

\section{Data analysis}

The data generated from body weight and morphometric measurements were subjected to Analysis of variance using Statistic 9.0. Significant means were compared by Least Significant Difference. The models were fitted to the chicken growth data using Levenberg- Marquardt nonlinear least-squares algorithm in Statistic 9.0 and curve parameters obtained.
Determination of goodness of fit

The asymptotic body weight (A), Akaike's information Criterion (AIC), Standard Deviation (SD) and Coefficient of Determination $\left(\mathrm{R}^{2}\right)$ were used for model comparison. Goodness of fit for each model was determined by using the coefficient of determination $\left(\mathrm{R}^{2}\right)$ and Akaike's Information Criterion (AIC) and Standard Deviation(SD).

\section{Results and discussion}

The effects of sex on body weight and morphometric traits of Noiler chickens at different ages are presented in Tables 1 and 2. The results showed that sex had significant $(\mathrm{p}<0.05)$ influence on body weights at 16, 18 and 20 weeks of age. At these ages, the males had superior body weight (2316.2, 2624.3 and $3002.7 \mathrm{~g}$, respectively) compared to the females (2121.9, 2378.1 and 2718.7 g). Similarly, body length differed significantly with sex at the later stages of growth $(14,16,18$ and 20 weeks of age). The corresponding values for male and female, respectively at these ages were 54.39 vs $36.73 \mathrm{~g}, 63.78$ vs 40.59 g, 71.94 vs $42.30 \mathrm{~g}$ and 80.69 vs $42.64 \mathrm{~g}$. However, sex did not significantly affect the other morphometric traits of Noiler chickens. This result indicated that the difference in weight and body length between male and female Noiler was only obvious at the later stages of growth. The superiority of males over females for body weight agrees with the findings of Kesheri et al. (1985) and Rondeli et al. (2003). These authors reported that males were heavier than females during the growing stage. The results of this study was in contrast to that of Al-Qamashoui et al. (2014) who reported significantly higher values for shank length for males $(8.1 \mathrm{~cm})$ compared to females $(7.1 \mathrm{~cm})$..Okpeku et al. (2003) also showed that shank length was higher in males $(9.52 \mathrm{~cm})$ than females $(8.99 \mathrm{~cm})$ for local chickens in Edo state. 


\section{Growth characteristics of noiler chickens as determined by nonlinear algorithms}

The reported differences may be as a result of the diverse genotypes used in the studies. Males were generally bigger and heavier than the females in this study probably due to the effect of hormonal differential on growth, which promotes greater skeletal and tissue growth in males compared to females. It has also been reported that sex difference in weight was usually due to difference in hormonal profiles, aggressiveness and dominance especially when both sex are reared together (Ibe and Nwosu, 1999). The results of wing length chest, girth, and chest weight showed no significant difference $(p<0.05)$ between males and females at all stages of growth. This agrees with the findings of Okpeku et al. (2003) who studied several breeds of chickens and reported that there were no significant differences in chest weight $(\mathrm{CW})$, Thigh length (TL) and wing length (WL) for both sexes. Apuno et al. (2011) also reported that breast girth was not affected by sex.

Both male and female Noiler chickens were 3.4 and $3.94 \%$ matured at 2 weeks of age. The birds were 70 and $76 \%$ matured at 14 weeks and $87 \%$ at 18 weeks. Though, females matured faster than males, the latter had higher matured weight.

Table 1: Means (g) and degree of maturity (DMAT\%) of body weight of male and female Noiler chickens at different ages

\begin{tabular}{ccccc}
\hline & \multicolumn{2}{c}{ Sex } & \multicolumn{2}{c}{ DMAT (\%) } \\
Age (weeks) & Male & Female & Male & Female \\
\hline 2 & $102.05 \pm 5.55$ & $107.22 \pm 4.22$ & 3.40 & 3.94 \\
4 & $252.73 \pm 13.72$ & $252.73 \pm 10.43$ & 8.42 & 9.30 \\
6 & $414.51 \pm 26.08$ & $409.97 \pm 10.83$ & 13.80 & 15.08 \\
8 & $865.31 \pm 30.02$ & $821.26 \pm 33.23$ & 28.82 & 30.21 \\
10 & $1129.39 \pm 43.21$ & $1081.24 \pm 41.11$ & 37.61 & 39.77 \\
12 & $1686.50 \pm 90.41$ & $1600 \pm 68.74$ & 56.17 & 58.85 \\
14 & $2095.70 \pm 220$ & $2076.6 \pm 167.7$ & 69.79 & 76.38 \\
16 & $2316.20 \pm 103.2^{\mathrm{a}}$ & $2121.9 \pm 77.81^{\mathrm{b}}$ & 77.14 & 78.05 \\
18 & $2624.30 \pm 104.3^{\mathrm{a}}$ & $2378.1 \pm 79.27^{\mathrm{b}}$ & 87.40 & 87.47 \\
20 & $3002.70 \pm 111.8^{\mathrm{a}}$ & $2718.7 \pm 84.99^{\mathrm{b}}$ & 100.00 & 100.00 \\
\hline
\end{tabular}

${ }^{\mathrm{a}, \mathrm{b}}$ Means in a subset within the same row bearing different superscripts are significantly different $(\mathrm{P}<0.05)$ DMAT $=$ degree of maturity

Table 2. Effect of sex on morphometric traits of Noiler chickens at different ages

\begin{tabular}{|c|c|c|c|c|c|c|c|}
\hline Age (weeks) & Sex & $\mathrm{BL}(\mathrm{cm})$ & TL (cm) & $\mathrm{SL}(\mathrm{cm})$ & WL (cm) & $\mathrm{CG}(\mathrm{cm})$ & $\mathrm{CW}(\mathrm{cm})$ \\
\hline \multirow[t]{2}{*}{2} & Male & $14.54+1.20$ & $3.40 \pm 0.15$ & $6.16 \pm 0.15$ & $7.46+0.20$ & $12.15 \pm 0.26$ & $3.86 \pm 0.06$ \\
\hline & Female & $12.56 \pm 0.91$ & $3.58 \pm 0.08$ & $6.00 \pm 0.11$ & $7.35 \pm 0.16$ & $12.19 \pm 0.20$ & $3.80 \pm 0.05$ \\
\hline \multirow[t]{2}{*}{4} & Male & $20.14 \pm 2.41$ & $7.35 \pm 0.12$ & $8.22 \pm 0.13$ & $12.01 \pm 0.15$ & $16.77 \pm 0.27$ & $5.22 \pm 0.07$ \\
\hline & Female & $16.39+1.81$ & $7.17 \pm 0.09$ & $8.13+0.13$ & $12.01 \pm 0.17$ & $16.77+0.27$ & $5.22 \pm 0.06$ \\
\hline \multirow[t]{2}{*}{6} & Male & $24.31+4.41$ & $8.62+0.23$ & $10.0 \overline{5}+0.24$ & $14.75 \pm 0.33$ & $21.22+0.54$ & $5.90 \pm 0.12$ \\
\hline & Female & $20.22 \pm 4.91$ & $8.62 \pm 0.23$ & $9.69 \pm 0.19$ & $14.62 \pm 0.25$ & $21.22 \pm 0.54$ & $5.90 \pm 0.12$ \\
\hline \multirow[t]{2}{*}{8} & Male & $27.56 \pm 4.43$ & $10.70 \pm 0.43$ & $12.5 \overline{3} \pm 0.23$ & $21.50 \pm 0.23$ & $28.60 \pm 0.78$ & $7.94 \pm 0.12$ \\
\hline & Female & $23.18+6.93$ & $9.95+0.33$ & $11.96 \pm 0.20$ & $21.71 \pm 0.23$ & $27.20 \pm 0.72$ & $7.53 \pm 0.12$ \\
\hline \multirow[t]{2}{*}{10} & Male & $31.23 \pm 6.45$ & $12.50 \pm 0.13$ & $12.99 \pm 0.25$ & $34.77 \pm 0.33$ & $32.62 \pm 0.82$ & $9.90 \pm 0.26$ \\
\hline & Female & $26.96 \pm 4.93$ & $11.73 \pm 0.17$ & $12.06 \pm 0.20$ & $34.10 \pm 0.25$ & $32.46 \pm 0.71$ & $9.54 \pm 0.21$ \\
\hline \multirow[t]{2}{*}{12} & Male & $34.77 \pm 2.15$ & $14.20 \pm 0.27$ & $14.74+0.26$ & $42.08+1.16$ & $37.51 \pm 0.95$ & $10.8 \overline{5} \pm 0.31$ \\
\hline & Female & $34.77 \pm 2.65$ & $13.68+0.20$ & $14.33 \pm 0.20$ & $43.78+0.88$ & $37.28+0.72$ & $11.09 \pm 0.24$ \\
\hline \multirow[t]{2}{*}{14} & Male & $54.39 \pm 8.40^{\mathrm{a}}$ & $14.76 \pm 0.23$ & $15.78 \pm 0.26$ & $50.02 \pm 0.86$ & $42.21 \pm 0.99$ & $10.49 \pm 0.21$ \\
\hline & Female & $36.73 \pm 3.73^{b}$ & $14.40 \pm 0.17$ & $15.45 \pm 0.20$ & $49.24 \pm 0.65$ & $41.38 \pm 0.75$ & $10.34 \pm 0.16$ \\
\hline \multirow[t]{2}{*}{16} & Male & $63.78 \pm 3.94^{\mathrm{a}}$ & $15.67 \pm 0.24$ & $17.00 \pm 0.28$ & $52.74 \pm 0.82$ & $42.87 \pm 1.01$ & $11.89 \pm 0.22$ \\
\hline & Female & $40.59 \pm 4.29^{b}$ & $15.00 \pm 0.18$ & $16.23 \pm 0.21$ & $52.00 \pm 0.62$ & $41.03 \pm 0.76$ & $11.78 \pm 0.16$ \\
\hline \multirow[t]{2}{*}{18} & Male & $71.94 \pm 4.68^{\mathrm{a}}$ & $15.90 \pm 0.27$ & $17.06 \pm 0.29$ & $55.08 \pm 1.03$ & $44.75 \pm 1.07$ & $13.28 \pm 0.25$ \\
\hline & Female & $42.30 \pm 3.69^{b}$ & $15.93 \pm 0.21$ & $16.68 \pm 0.22$ & $55.08 \pm 1.02$ & $43.92 \pm 0.81$ & $13.32 \pm 0.19$ \\
\hline \multirow[t]{2}{*}{20} & Male & $80.69 \pm 7.95^{\mathrm{a}}$ & $16.51 \pm 0.26$ & $17.30 \pm 0.27$ & $55.52 \pm 0.90$ & $46.25 \pm 0.99$ & $14.71 \pm 0.26$ \\
\hline & Female & $42.64 \pm 4.06^{\mathrm{b}}$ & $16.06 \pm 0.20$ & $16.84 \pm 0.21$ & $54.25 \pm 0.68$ & $43.92 \pm 0.75$ & $14.47 \pm 0.20$ \\
\hline
\end{tabular}


Estimated coefficients for all models and the goodness of fit criteria of body weight and morphometric traits of male Noiler chickens are presented in Table 2. All models had considerably high coefficients of determination $\left(\mathrm{R}^{2}\right)$ values $(0.81-0.93)$ for body weight and morphometric traits of male Noilers. This indicates that the growth curves of the observed data were adequately described by the moels for all traits. The asymptotic weight (A) for all the traits were higher for the Gompertz than Logistic model while the reverse was the case for the scale parameter (B) and relative growth rate (C). Thus, for all traits, the Gompertz had higher asymptotic weight but lower scale parameter and relative growth rate. The asymptotic weight for body weight of male Noilers as determined by the Gompertz model is $3891.90 \mathrm{~g}$ with $\mathrm{B}$ and $\mathrm{C}$ values of
1.58 and 0.13 , respectively. The corresponding values for the Logistic models were $3133.60 \mathrm{~g}, 3.55$ and 0.29 . The model with a better fit can be determined from the values of the goodness of fit criteria; coefficients of determination $\left(\mathrm{R}^{2}\right)$, standard deviation and Akaike information criterion (AIC), usually, the best model is one with higher coefficient of determination $\left(\mathrm{R}^{2}\right)$ and lower Akaike information criterion (AIC) and standard deviation. The $\mathrm{R}^{2}$, AIC and SD of the Gompertz for body weight were $0.812,6927.50$ and 511.01 with corresponding values of $0.810,6933$ and 513.55 for the Logistic. A similar trend was observed for all morphometric traits. Thus, the Gompertz model consistently had higher $\mathrm{R}^{2}$ and lower AIC and SD for all traits compared to the Logistic.

Table 3: Model parameters and goodness of fit criteria for different growth models fitted to the body weight and morphometric traits of male noiler chickens

\begin{tabular}{|c|c|c|c|c|c|c|c|c|c|}
\hline Trait & parameter & & A & B & $\mathrm{C}$ & AIC & & $\mathrm{R}^{2}$ & SD \\
\hline \multirow[t]{2}{*}{$\overline{\mathrm{BW}}$} & Gompertz & 3891.9 & 1.5858 & 0.1396 & 6927.5 & 0.8122 & 511.01 & & \\
\hline & Logistic & 3133.6 & 3.5544 & 0.2900 & 6933.0 & 0.8103 & 513.55 & & \\
\hline \multirow[t]{2}{*}{ BL } & Gompertz & 50.528 & 0.6701 & 0.1322 & 1395.3 & 0.9290 & 3.4991 & & \\
\hline & Logistic & & 46.854 & 1.7775 & 0.2055 & 1412.6 & 0.9267 & 3.5538 & \\
\hline \multirow[t]{2}{*}{ TL } & Gompertz & & 16.26 & & 0.8567 & 0.2406 & 446.00 & 0.9161 & 1.4888 \\
\hline & Logistic & & 15.810 & 1.7775 & 0.3497 & 488.08 & 0.9085 & 1.5464 & \\
\hline \multirow[t]{2}{*}{ SL } & Gompertz & 17.826 & 0.5635 & 0.1957 & 521.24 & 0.8966 & 1.5921 & & \\
\hline & Logistc & 17.301 & 1.2849 & 0.2732 & 540.07 & 0.8989 & 1.6193 & & \\
\hline \multirow[t]{2}{*}{ WL } & Gompertz & 62.341 & 1.2918 & 0.1856 & 1852.9 & 0.9373 & 5.2843 & & \\
\hline & Logistic & & 57.524 & 2.7418 & 0.3146 & 1822.0 & 0.9407 & 5.1391 & \\
\hline \multirow[t]{2}{*}{ CG } & Gompertz & 49.733 & 0.7649 & 0.1660 & 1571.0 & 0.9201 & 40989 & & \\
\hline & Logistic & & 46.980 & 1.6683 & 0.2527 & 1580.7 & 0.9187 & 4.1349 & \\
\hline \multirow[t]{2}{*}{$\mathrm{CW}$} & Gompertz & 27.316 & 0.7744 & 0.0604 & 476.92 & 0.897 & 1.2786 & & \\
\hline & Logistic & & 20.298 & 1.6275 & 0.1246 & 493.73 & 0.8953 & 1.2898 & \\
\hline
\end{tabular}

$\overline{\mathrm{A}}=$ Asymptiomatic weight $\mathrm{B}=$ Scale parameter (contsant), $\mathrm{C}=$ Relative growth rate, AIC =Akaike's formattion criteria, $\mathrm{R} 2$ = coefficient of deternination, $\mathrm{SD}=$ standard deviation, $\mathrm{BW}=$ body weight, $\mathrm{BL}$ =body length, $\mathrm{TL}=$ Thigh length, $\mathrm{SL}=$ Shank length, $\mathrm{WL}=$ Wing length, $\mathrm{CG}=$ Chest girth, and $\mathrm{CW}=\mathrm{Chest}$ width.

Model parameters and goodness of fit criteria for different growth models fitted to the body weight and morphometric traits of female Noiler chickens are shown in Table 3. The coefficient of determination for body weight and morphometric traits of female Noiler chickens were generally high (0.67-
0.94). This implies that the models adequately fit the observed body weight and morphometric traits data of the chickens. The Gompertz model had consistently higher $\mathrm{R}^{2}$ than Logistic for most traits except tail length where the reverse was the case. As was observed for male Noiler 


\section{Growth characteristics of noiler chickens as determined by nonlinear algorithms}

chickens, the Gompertz model had higher asymptote values and lower scale parameter and relative growth rate compared to the Logistic for all the traits studied in their female counterparts. The asymptote value for body weight as estimated by the Gompertz model was $3365.9 \mathrm{~g}$ compared to $2817.2 \mathrm{~g}$ for the Logistic. A similar trend was observed for all the morphometric traits. The Gompertz model also had lower scale parameter and relative growth rate than the Logistics for all traits. Similarly, the values of Akaike Information Criteria (AIC) and Standard deviation were lower for the Gompertz model compared to the Logistic for all traits. Thus, the Gompertz model had higher $\mathrm{R}^{2}$ and lower AIC and SD than the Logistic. This implies that the Gompertz describes the growth curve of the female Noiler chickens better than the Logistic. Masoudi and Azarfa (2017) stated that the best model is that with a higher coefficient of determination $\mathrm{R}^{2}$ and lower Akaike information Criterion (AIC).

Table 4: Model Parameters and Goodness of fit criteria for different growth models fitted to the Body weight and Morphometric trait of female Noiler chicken

\begin{tabular}{|c|c|c|c|c|c|c|c|c|}
\hline Trait & Parameter & A & B & $\mathrm{C}$ & AIC & $\mathrm{R}^{2}$ & SD & \\
\hline \multirow[t]{2}{*}{$\overline{\mathrm{BW}}$} & Gompertz & 3365.9 & 1.5832 & 0.1518 & 12319 & 0.7250 & 610.12 & \\
\hline & Logistic & & 2817.2 & 4.5081 & 0.3021 & 12325 & 0.7233 & 611.97 \\
\hline \multirow[t]{2}{*}{ BL } & Gompertz & 46.673 & 0.6541 & 0.1529 & 3294.7 & 0.8298 & 5.5475 & \\
\hline & Logistic & & 44.228 & 1.645 .7 & 0.2270 & 3307.3 & 0.8298 & 5.5842 \\
\hline \multirow[t]{2}{*}{$\mathrm{TL}$} & Gompterz & 16.140 & 0.7949 & 0.2208 & 3289.2 & 0.8276 & 5.5475 & \\
\hline & Logistic & & 15.672 & 1.6574 & 0.3145 & 720.86 & 0.9144 & 1.4518 \\
\hline \multirow[t]{2}{*}{ SL } & Gompertz & & 16.93 & & 0.5521 & 0.2152 & 2161.1 & $0.6744 \quad 0.6744$ \\
\hline & Logistic & & 16.525 & 1.2561 & 0.2964 & 2172.9 & 0.6704 & 3.0965 \\
\hline \multirow[t]{2}{*}{ WL } & Gompertz & 60.260 & 1.3192 & 0.1973 & 3058.7 & 0.9442 & 49059 & \\
\hline & Logistic & & 56.120 & 2.7783 & 0.3302 & 2979.5 & 0.9437 & 4.7076 \\
\hline \multirow[t]{2}{*}{ CG } & Gompertz & 47.692 & 0.7718 & 0.1784 & 2649.0 & 0.9212 & 3.9633 & \\
\hline & Logistic & & 45.325 & 1.6799 & 0.2699 & 2654.5 & 0.9208 & 39746 \\
\hline \multirow[t]{2}{*}{$\mathrm{CW}$} & Gompertz & & 27.31 & & 0.1744 & 0.0604 & 476.92 & 089711.2786 \\
\hline & Logistic & & 20.298 & 1.6275 & 0.1246 & 493.73 & 0.8953 & 1.2898 \\
\hline
\end{tabular}

$\mathrm{A}=$ Aymptomatic weight, $\mathrm{B}=$ scale parameter (constant), $\mathrm{C}=$ Relative growth rate, $\mathrm{AIC}=$ Akailke`s Information criteria, $\mathrm{R} 2 \quad=$ coefficient of determination, $\mathrm{SD}=$ Standard deviaton, $\mathrm{BW}=$ Body weight $\mathrm{BL}=$ body length, $\mathrm{TL}=$ thigh length, $\mathrm{SL}=$ Shank length, $\mathrm{WL}=$ Wing length, $\mathrm{CG}=$ Chest girth, and $\mathrm{CW}=$ Chest width

\section{Conclusions}

The study showed that only body weight and length of male and female Noiler chickens differed and such differences were more obvious during the later growing phase with the male having higher values than the female. Though, both the Gompertz and Logistic models adequately described the growth of Noiler chickens (high $\mathrm{R}^{2}$ ), the Gompertz was better when the other goodness of fit criteria; AIC and SD were considered. The Gompertz model is therefore recommended for describing growth of male and female Noiler chickens.

\section{References}

Al-Qamasgoui, B., Mohgoub, O., Kadim, L. and Schlechi, E. 2014. Toward conservation of Omani local chicken:phenotipic characteristic management practices and performance traits .Asain Journal of Animal Science 6:178-182

Apuno, A., Mbap, S. and Ibrahim, T. 2011. Characterization of local chickens (Gallus gallus domesticus) in Shelleng and song local government area of Adamawa State Nigeria. Journal of 
Agriculture and Biology of North America 2:6-14

Bates, D. M., and Watts, D. G. 2007. N onlinear Regression analysis and its application. Wiley Ser. Probab-. Stat. John Wiley and Sons, New York, USA.

Essien, A. L. and Adeyemi, J. A. 1999. Comparative growth characteristic of two broiler strains raised in the wet humid tropics.Tropical Journal of Animal science. 1(2):1-8

FAO, 2010. Small Scale poultry production (Technical guide) by Sonaiya and Swan FAO. Animal production and Health manual No 1.

Fayeye, T. R., Adashiyan, A. B. and Olugband, A. A. 2005. Egg trait hatchability and early growth performance of the Fulani ecotype chickens. Journal of Agriculture 17

Ibe, S. N. and Ezekwe, A.G. 1995. Quantifying Size and shape differences between Muturu and N'Dama breeds of cattle. Nigeria Journal of Animal Production 8:15

Kellou, K. M. 2005. Development of multinational block for dry season supplementary feeding of sheep in a semi- arid environment. Msc. Thesis Department of Animal Science University of Maiduguri Nigeria. Pp 23-38

Keshri, R. C., Verma, S. S., Sinha, S. P., Sharma, R. P., Singh, P. B., Ray, A. K. D. and Shyamsunder, G. 1985. The relationship between pure bred broiler strain. Indian Journal of Poultry Science. 20 (4);297-299.

Laird, A. K., Tyler, S. A., and Burton, A. D., 1965. Dynamic of Normal growth. Growth 29: 233-248. 248

Mignon-Grastea, S., Beaumont, C., and Ricard, F.H., 2001. Genetic analysis of a selection experiment on the growth curve of chickens. Journal of Poultry Science.80:84954:7SS

Narine, D., Oksuz, N.,and Aygum, A., 2017. Growth curve analyses in poultry science. Journal of Poultry Science, 73:395-408).

Nwosu, C. C. and Asuquo, B. O. 1995. Body weight improvement in local chicken. Proceeding 10th Annual conference. Nigeria society for Animal Production IIe-Ife. Nigeria.23-29

Ogundipe, S. O. S. and Sanni, S. A. 2002. Economic of poultry production in Nigeria a Training manual of poultry production in Nigeria. NAPRI A.B.U.Zariapp 245.

Okpeku, M., Orherauta, M. and Imumorin, I. G. 2003. Phenotipic and genotyic variation among local chickens. Nigeria livestock. A Gold mine for economic growth and food security. Proceeding of the 8th Annual conference of the Nigeria society for Animal Production, 1620 March,Ibaban 28:119-121.

Raji, A. O., Alade, N. K. and Duwa, H. 2014. Estimations of model parameters of the Japanese quail growth curve using Gompertz model. Archivos Zootechnia 63 (4):29-35

Robertson, T. B., 1923. The chemical basis of growth and senescence. Monograph of Experimental Biology. J.B. Lippincott. Philadelphaia, PA.

Rondelli, S., Martinez, O., and Gracia, P. T., 2003. Sex effect on production parameters, carcass and body fat composition of two commerciall broilers chickens. Journal of Poultry Science 5 (3); 169-173.

Selvaggi, M., Laudadio, V. and Dario, C. 2015. Modelling growth curves in a nondescript ltalian chicken breed: 
Growth characteristics of noiler chickens as determined by nonlinear algorithms

An opportunity to improve genetic and feeding strategies. Journal of poultry Science. 52 (2):88-94.

Statistic for windows Manual. Copyright@19852008. Analytical Software, Version 9.0, Tallahasse FL, USA, 2008.

Yakubu, A. and Ari, M. M. 2018. Principal component and discriminate analyses of bodyweight and conformation traits of Sasso, Kuroiler and indigenous Fulani chickens in Nigeria. Journal of Animal and Plant Science.
Yakubu, A., Salako, A. E. and Ige, A. O. 2007. Effect of genotype and housing system on the laying performance of chickens in different seasons in the Semi Humid Tropics. International Journal of Poultry Science, 6:4349.

Received: $10^{\text {th }}$ May, 2021

Accepted: $15^{\text {th }}$ August, 2021 